\title{
Bovine fetal testicular development in the Nellore breed
}

\section{Desenvolvimento testicular fetal bovino na raça Nelore}

\author{
Juliana Stephany de Souza ${ }^{1}$; Maria Carolina Villani Miguel ${ }^{1}$; Marcos Antônio \\ Maioli ${ }^{1}$; Arthur Nelson Trali Neto ${ }^{1}$; David Giraldo Arana ${ }^{1}$; Alexandre Rossi \\ Laurini $^{1}$; Guilherme de Paula Nogueira ${ }^{2 *}$
}

\begin{abstract}
The study of gonadal development improves the understanding of factors that can influence the reproductive development process. This study aims to characterize bovine fetal testicular development and the testosterone level in the Nellore breed. For the study, 162 bovine fetuses aged between 3 and 8 months were collected from Nellore cows at a local abattoir. The fetal age was estimated by $\mathrm{DP}=8.4+0.087 \mathrm{~L}+5.46 \sqrt{\mathrm{L}}$, where $\mathrm{DP}$ is the estimated pregnancy day and $\mathrm{L}$ represents fetal length. The fetal gonadal weight $(\mathrm{g})$, width $(\mathrm{cm})$, and thickness $(\mathrm{cm})$ were measured. Thereafter, the gonads were submitted to classic histology processes in 3- $\mu \mathrm{m}$-thick slices cut at $210 \mu \mathrm{m}$ intervals. The Sertoli cells, Leydig cells, and germ cells were counted. Blood samples were collected from umbilical cords for testosterone levels. The data were analyzed using the Spearman correlation test followed by Principal Component Analysis and one-way ANOVA to compare the averages between months. The testicular weight and volume were found to have a positive correlation with the numbers of Sertoli cells $(r=0.84$; $\mathrm{p}<0.0001$ and $\mathrm{r}=0.92 ; \mathrm{p}<0.0001$, respectively), Leydig cells $(\mathrm{r}=0.80 ; \mathrm{p}<0.0001$ and $\mathrm{r}=0.90 ; \mathrm{p}$ $<0.0001$, respectively), and germ cells $(r=0.84 ; \mathrm{p}<0.0001$ and $\mathrm{r}=0.93 ; \mathrm{p}<0.0001$, respectively) and to be negatively correlated with testosterone plasmatic concentration $(\mathrm{r}=-0.31 ; \mathrm{p}=0.0001$ and $r=-0.22 ; p=0.006$, respectively) during pregnancy. After the fifth month, the numbers of Sertoli cells, Leydig cells and germ cells differed $(p<0.0001)$ from the following gestational months. The highest testosterone concentration $(\mathrm{p}=0.007)$ was observed in the fifth month of gestation and was followed by a concentration decrease in the seventh and eighth months. The increase in cell quantity was responsible for the increase in testicular weight and volume during fetal development. On the other hand, the testosterone concentration followed the increase in testicular weight and volume until the $7^{\text {th }}$ month of gestation and regressed during the $8^{\text {th }}$ and $9^{\text {th }}$ months, in addition to the increase in cell number. Key words: Germ cells. Pregnancy. Sertoli cells. Testicle interstitial cells. Testosterone concentration.
\end{abstract}

\section{Resumo}

O estudo do desenvolvimento gonadal melhora o entendimento dos fatores que podem influenciar o processo de desenvolvimento reprodutivo. Esse estudo objetivou caracterizar o desenvolvimento testicular bovino e os níveis de testosterona na raça Nelore. Para o estudo, 162 fetos bovinos com idade entre 3 e 8 meses foram coletados de vacas Nelore em frigorífico local. A idade fetal foi estimada pela fórmula $\mathrm{DP}=8.4+0.087 \mathrm{~L}+5.46 \sqrt{\mathrm{L}}$, onde $\mathrm{DP}$ corresponde ao dia estimado de gestação e $\mathrm{L}$ representa o comprimento fetal. Foram medidos o peso gonadal fetal $(\mathrm{g})$, a largura $(\mathrm{cm})$ e a espessura $(\mathrm{cm})$. Após

1 Discentes, Faculdade de Medicina Veterinária, Universidade Estadual Paulista Júlio de Mesquita Filho, FMVA/UNESP, Araçatuba, SP, Brasil. E-mail: ju_juliss@hotmail.com; mcvmiguel@hotmail.com; maioli_marcos@hotmail.com; arthur_tralli_ neto@hotmail.com; davidgiar@hotmail.com; ale.laurini@yahoo.com.br

2 Prof., FMVA/UNESP, Araçatuba, SP, Brasil. E-mail: gpn@fmva.unesp.br

* Author for correspondence

Received: Sept. 25, 2016 Approved: Oct. 10, 2016 
as mensurações, as gônadas foram submetidas ao processamento histológico clássico, sendo utilizadas para elaboração das lâminas cortes com $3 \mu \mathrm{m}$ de espessura com intervalos entre cortes de $210 \mu \mathrm{m}$. As células de Sertoli, Leydig e germinativas foram contadas. Amostras de sangue foram coletadas do cordão umbilical para quantificação dos níveis de testosterona. Os dados foram analisados utilizando a correlação de Spearman seguida pela análise de componentes principais, sendo o comparativo de médias entre os meses realizados utilizando o one-way ANOVA. O peso e o volume testicular apresentaram correlação positiva com o número de células de Sertoli $(r=0,84 ; \mathrm{p}<0,0001$ e $\mathrm{r}=0,92 ; \mathrm{p}<0,0001$, respectivamente), células de Leydig $(r=0,80 ; p<0,0001$ e $r=0,90 ; p<0,0001$, respectivamente), e células germinativas $(\mathrm{r}=0,84 ; \mathrm{p}<0.0001$ e $\mathrm{r}=0,93 ; \mathrm{p}<0,0001$, respectivamente), porém foram negativamente correlacionados com a concentração plasmática de testosterona $(\mathrm{r}=-0,31 ; \mathrm{p}=0,0001$ e $\mathrm{r}=-0,22 ; \mathrm{p}=0,006$, respectivamente) durante a gestação. Após o quinto mês, o número de células de Sertoli, de Leydig e germinativas diferiram $(p<0,0001)$ dos meses seguintes de gestação. A maior concentração de testosterona encontrada $(\mathrm{p}<0,007)$ foi observada no quinto mês de gestação, sendo seguida por uma diminuição entre o sétimo e oitavo mês. $O$ aumento na quantidade de células durante o desenvolvimento fetal foi o responsável pelo aumento do peso e volume testicular. Por outro lado, a concentração de testosterona seguiu o aumento no peso e volume testicular até o $7^{\circ}$ mês de gestação, regredindo durante o $8^{\circ}$ e $9^{\circ}$ mês com o aumento do número de células.

Palavras-chave: Células de sertoli. Células germinativas. Células testiculares intersticiais. Concentração de testosterona. Gestação.

\section{Introduction}

Failure in reproduction is a factor that limits beef cattle production (PESSUTI; MESSADRI, 2004). Cattle breeding has an increasing demand for animals of high genetic value, thus boosting the use of animal breeding biotechnologies. Changes arising from the fetal period may harm the reproductive system in adulthood by preventing phenotypic expression in the animal with a given genotypic potential, thus compromising genetic selection for insemination programs (REYNOLDS et al., 2010). The knowledge of factors that may affect prenatal gonad development can allow management that improves the physiological and reproductive profile of an animal.

Knowledge about spermatogenesis and testicular physiology is fundamental to understanding the factors that interfere with sperm production and the identification of potential causes of infertility and subfertility in males (REYNOLDS; CATON, 2012). Sertoli cells produced during the fetal stage determine the quantity of germ cells evolved in spermatogenesis and are echoed in the sperm production volume during the adult life of an animal (SHARPE et al., 2003). Furthermore, the testicular mass can be used to assess the sperm production capacity of the testicular parenchyma; this mass is also correlated with the animal semen quality (GUERRA et al., 2013). The bull scrotal circumference is correlated with the age at puberty of the bull's daughters (MOSER et al., 1996) and with the scrotal diameter of the bull's sons (BRINKS et al., 1978). However, most studies have been performed using European breeds (Bos taurus).

The objective of this study was to characterize the components involved in fetal testis prenatal development according to the month of gestation in Nellore cattle.

\section{Materials and Methods}

\section{Animals}

Male fetuses $(n=162)$ were collected from cows with Nellore breed characteristics (ACBN, 2013) slaughtered in an abattoir in the AraçatubaSP region $\left(20^{\circ} 53\right.$ ' 45 "S and $51^{\circ} 22$ ' $44^{\prime}$ " W). The length of the fetuses was measured with a tape measure (graduated in $\mathrm{mm}$ ) at the time of fetal 
removal from the uterus. The distance between the sagittal external line of the frontal bone and the first coccygeal vertebra (crown rump measurement) was measured in centimeters. This value was used to estimate the fetal age (REXROAD et al., 1974; $\mathrm{DP}=8.4+0.087 \mathrm{~L} 5,46 \sqrt{\mathrm{L}}$, where $\mathrm{DP}=$ days of pregnancy and $\mathrm{L}=$ length of the fetus).

The fetuses were grouped according to the estimated month of pregnancy. The number of collected fetuses was 16 in the 3rd month, 22 in the 4th month, 33 in the 5th month, 39 in the 6th month, 32 in the 7 th month and 20 in the 8th month of gestation.

\section{Fetal gonad harvesting and processing}

After removal of the fetuses, the testes were stored in $100 \mathrm{~mL}$ containers with lids, and the volume was completed with 4\% paraformaldehyde for tissue preservation and fixation for histological analysis. The testicular weight was determined on a scale (Mettler Toledo, AG285), and the testicular length (1), width (w) and thickness (t) were measured in millimeters using a steel caliper (Brasfort, Brazil,160 mm/6", with an accuracy of $0.02 \mathrm{~mm} / 0.001$ "). The testicular volume was estimated using the ellipsoid formula based on the geometric structure that resembles testis shape.

\section{Histological processing of the fetal testis}

The testes were fixed in $4 \%$ paraformaldehyde after they were removed from the fetus. They went through a dehydration process by increasing ethanol concentrations followed by diaphanization in xylene. Finally, they were immersed in Paraplast ${ }^{\circledR}$ Plus (Sigma-Aldrich P3683). After inclusion, serial 3 - $\mu$ m-thick sections were created using the Leica rotary microtome (RM1255 model). Histological slides were mounted with a mean interval of $210 \mu \mathrm{m}$ between cuts and were stained with hematoxylineosin (HE) (JACOMINI et al., 2007). After these procedures, the germ cells, Sertoli cells and Leydig cells in the testes were counted. The same operator performed all steps and methods.

Germ, Sertoli and Leydig cells: cell identification and quantification

The Sertoli, Leydig, and germ cells were classified according to previously described characteristics (JUNQUEIRA, CARNEIRO 2004; JACOMINI et al., 2007).

The morphology of primordial germ cells, Sertoli cells and Leydig cells were analyzed using histological sections of the fetal testes by an Olympus (Japan) light microscope PW10 with 100X magnification, under which the nucleus diameter of the evaluated cells was measured.

Fields on the histological slide were evaluated for the number of cells. On the largest diameter of the testicular cut, six representative fields were evaluated in the longitudinal direction. The average number of each cell type was multiplied by the slice thickness $(3 \mu \mathrm{m})$ to obtain the number of cells per $\mu \mathrm{m}^{3}$ that was then transformed into $\mathrm{mm}^{3}$ and multiplied by the total testis volume. To avoid count duplication of the same cell in more than one section and to correct for the number of sections in which a cell could be included, the cell diameter was divided by the thickness of the cut, and the total number of cell types counted was divided by this value. As a result, the total number of fetal testis cells was obtained (JACOMINI et al., 2007), and the nucleus diameter of each cell type was used as a reference for determining the quantity of testicular cells.

\section{Blood samples}

The fetal blood sample was sampled from the umbilical cord during the removal of the fetus from the mother's uterus and collected in test tubes (10 $\mathrm{mL}$ ) with $50 \mathrm{~mL}$ of EDTA (Vacutainer ${ }^{\circledR}$ ). The blood samples were refrigerated until plasma separation 
by centrifuging at $2665 \mathrm{xg}$ for 10 minutes at $4^{\circ} \mathrm{C}$ in a centrifuge (Model CT-5000R Cientec). The plasma fractions were aliquoted in duplicate in $2 \mathrm{~mL}$ tubes (Axigen Scientific MCT-200B) and were stored in a freezer at $-20^{\circ} \mathrm{C}$. Hormone quantification of the fetal testosterone in the blood samples was performed by radioimmunoassay.

\section{Hormonal quantification}

Bovine testosterone quantification was performed using the Immunotech kit RIA (IM 1119). The intra-assay CV was $2.25 \%$ for the high control (4.6 ng/mL) and $0.69 \%$ for the low control $(0.76 \mathrm{ng} / \mathrm{ml})$, the inter-assay CV was $3.12 \%$ for the high control and $8.12 \%$ for the low control, and the assay sensitivity was $0.032 \mathrm{ng} / \mathrm{mL}$.

\section{Statistical analysis}

Spearman correlation was used to investigate the correlation between the populations of germ cells, Sertoli cells and Leydig cells of the testicles with the testicular weight and volume and the testosterone concentration during pregnancy. A $\mathrm{p}<0.05$ was used as the variables were not normally distributed. Principal Component Analysis (PRINCOMP) was performed to assess the variables that incorporated higher variability from the original data (SAS, 2009). For the variance comparison between the means of each gestational age group, a one-way ANOVA test was used. This statistical procedure was performed by the Prism 6.0 GraphPad program and the same program was used for chart preparation.

\section{Results and Discussion}

Within the seminiferous tubules, two cell types were observed: Sertoli cells and germ cells, as previously described (CARDOSO, 1977). The germ cells occupied the central area of the testis, and the Sertoli cells (support cells) were bounded by the tunic, forming the seminiferous cords.

The testes appeared to have developed equally as similar correlations between the number of cells and fetal age were observed; there was no change in the correlation between the components analyzed according to age (Figure 1).

Between the third and fifth months of pregnancy, the average number of Sertoli cells did not differ, with an estimated population of $7,722,243 \pm 8,545,334$ cells. However, from the sixth month, a significant increase in the number of cells was observed $(p<0.0001$; Figure 1$)$. In the sixth month of pregnancy, there were $33,118,196 \pm 19,371,179$ cells; in the seventh month, there were 58,924,506 $\pm 37,061,241$ cells; and in the eighth month, there were $168,773,440 \pm 78,305,092$ cells. Similar to cattle, the number of Sertoli cells at the end of pregnancy in humans is approximately 260 million. This number increases to 1.5 billion by 10 years of age and is estimated at 3.7 billion cells in human adults (CORTES et al., 1987). During pregnancy, some variation in the number of Sertoli cells in the testes of Nellore bovine fetuses was described (JACOMINI et al., 2007). The Sertoli cells are the first somatic cells to differentiate in the male gonad, and they act as central regulators of testis organogenesis (SVINGEN; KOOPMAN, 2013). 
Figure 1. Numbers of Sertoli, Leydig and germ cells, testicular volume and weight, and testosterone concentration of 162 male fetuses according to gestation month ( 3 months $n=16,4$ months $n=22,5$ months $n=33,6$ months $n=$ 39,7 months $n=32$, and 8 months $n=20$ ). Most of the variables showed a positive correlation with gestational age, except that testosterone concentration showed a negative correlation.
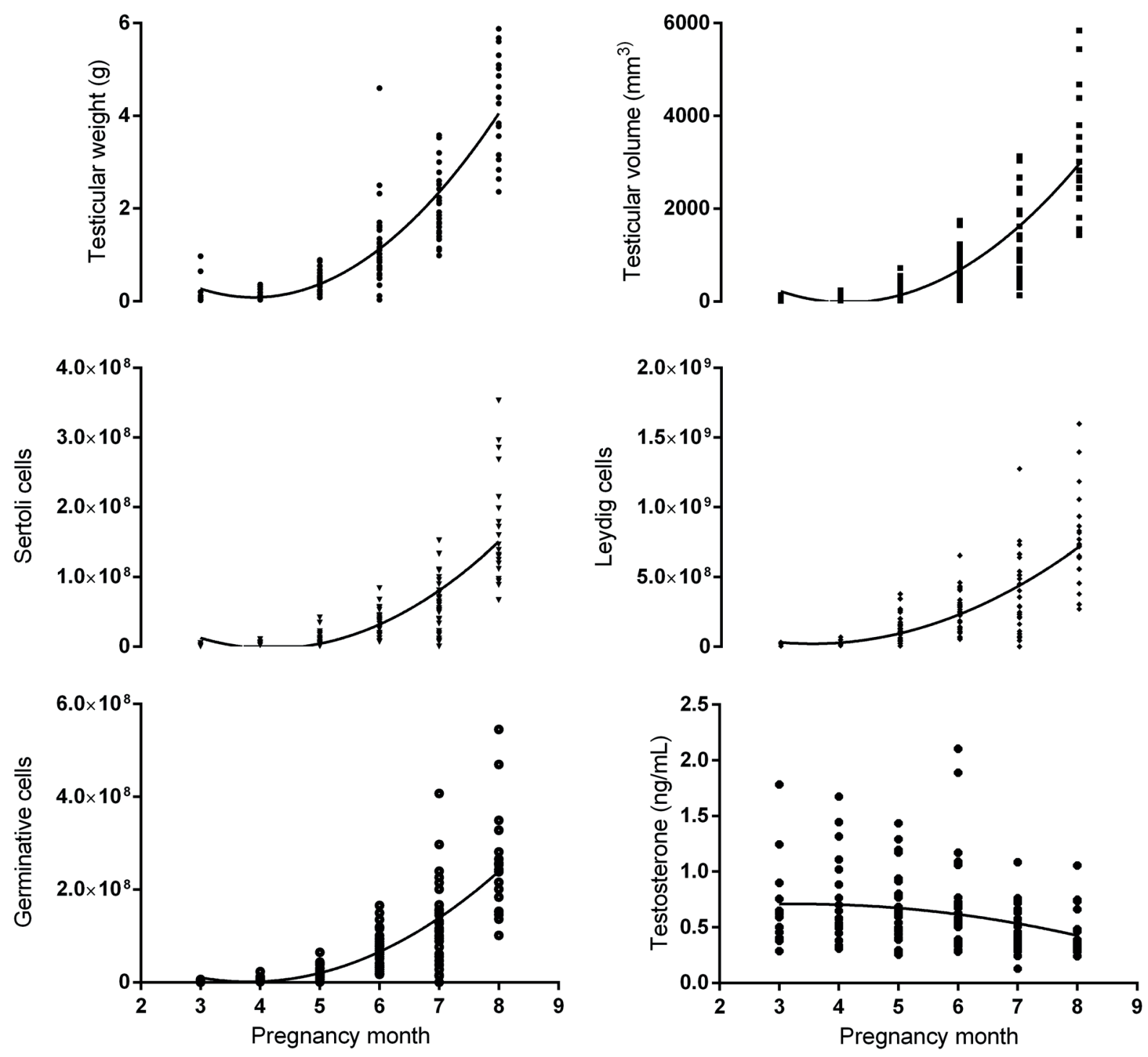

Similar to Sertoli cells, the estimated number of Leydig cells increased after the sixth month of pregnancy $(\mathrm{p}<0.0001 ;$ Figure 1$)$. The estimated number of Leydig cells was 71,600,147 $\pm 83,603,958$ until the fifth month, $246,90775 \pm 149,285,595$ in the sixth month, $364,517,929 \pm 274,354,630$ in the seventh month, and 776,550,366 $\pm 339,297,745$ in the eighth month. In human fetal testes, the Leydig

cell number begins to increase from the eighth week of pregnancy, and then the cells differentiate, multiply and increase in size until the 14th week (FRANCAVILLA et al., 1990). However, in mice, a smaller number of Leydig cells was reported, and the number increases continuously until adulthood (MENDIS-HANDAGAMA; ARIYARATNE, 2001).

A small number of germ cells was observed 
after the third month of pregnancy. In this work, the germ cells were in the seminiferous tubules, and large cells with lightly stained, rounded nuclei, as previously reported (JACOMINI et al., 2007), are formed from 31 days of gestation (WROBEL; SUB, 1998). It was observed that after the fifth month of pregnancy, the number of these cells increased according to age $(p<0.0001$; Figure 1$)$. The estimated number of primordial germ cells in the fetal testis was $7,362 \pm 1,232$ up to 5 months, $27,096 \pm 14,967$ at six months, 32,693 $\pm 23,500$ at seventh months and $63,550 \pm 38,302$ at eighth months of pregnancy. These values were lower than previously described in cattle (JACOMINI et al., 2007; MATSCHKE; ERICKSON, 1969; HOCHEREAU-DE REVIERS, et al., 1995) and humans (MULLER; SKAKKEBAEK, 1992). However, all of these works described an increase in the number of cells during pregnancy.

The testosterone concentration of fetal plasma differed between the months of pregnancy $(\mathrm{p}=0.007)$, and this value was greatest in the fifth month $(0.67 \pm 0.3 \mathrm{ng} / \mathrm{ml} ; \mathrm{p}=0.007)$, followed by a decrease in the seventh and eighth months $(0.45 \pm 0.16 \mathrm{ng} /$ $\mathrm{ml}$ and $0.44 \pm 0,15 \mathrm{ng} / \mathrm{ml}$, respectively; Figure 1). The change in testosterone concentration was likely a result of a modification in the production control system (or even an extra gonadal source). During the beginning of the fetal stage, androgen production occurs regardless of gonadotropins on the Leydig cells (SVINGEN; KOOPMAN, 2013) and is necessary for fetal sexual differentiation. It is likely that the change in the control and production system, with greater dependence on gonadotropins, produces this decrease in testosterone concentration as pregnancy progresses. In humans, an increase in testosterone production is described between the 4th and 5th months of pregnancy, followed by a subsequent decline (SWERDLOFF; HIKIM SINHA, 2009). In sheep, the highest testosterone concentration was found at approximately 70 days of gestation (FORD; D’OCCHIO, 1989), which is closer to the results found in Bos indicus fetuses. During pregnancy, the increase in androgen concentration is influenced by maternal sources and by the male fetus itself (CONNOLLY et al., 2013).

This study noted a positive correlation between the number of Sertoli cells and the testicular weight $(r=0.84 ; p<0.0001)$ and volume of fetuses $(r=0.92 ; p<0.0001$; Figure 2$)$; the same correlations occurred with the number of Leydig cells in the testes $(\mathrm{r}=0.80 ; \mathrm{p}<0.0001$ and $\mathrm{r}=0.90, \mathrm{p}<0.0001$, respectively; Figure 2). The positive correlation between the number of cells and the testicular weight and volume strengthens the assumption that both cells equally play a role in testis development. There is a report of a positive correlation between the number of Sertoli cells and testicular weight in Nellore cattle (CARNEIRO JUNIOR et al., 2001). Furthermore, in Bos taurus bulls, heavier testicles with a greater diameter had a higher ratio of round spermatids/Sertoli cells in the seminiferous tubules (MOURA; ERICKSON, 1997) and consequently higher sperm production (BERNDTSON et al., 1987). The relationship between Sertoli/spermatid cells is reflected in the potential sperm production of the animal in adulthood (AGUIAR et al., 2006).

A $96 \%$ correlation $(p<0.0001)$ was found between the number of Sertoli cells and Leydig cells in the fetal testis. Considering the assumption raised above, both the increase in testicular interstitium and the seminiferous tubules occurred in parallel during testicular development. In pigs, the Leydig cell differentiation is dependent upon Sertoli cell differentiation (KAMINSKI et al., 1999). In the fetal period, the Sertoli cells are functionally immature but are proliferative, allowing for the formation of cell cords in the seminiferous epithelium, preventing germ cells from entering meiosis and preventing the early differentiation and activity of Leydig cells (MACKAY, 2000).

The plasma testosterone concentration was negatively correlated with the testicular weight and volume $(\mathrm{r}=-0.31, \mathrm{p}=0.0001$ and $\mathrm{r}=-0.22 ; \mathrm{p}=0.006$, respectively; Figure 3 ) and with the number of 
Sertoli cells $(\mathrm{r}=-0.23, \mathrm{p}=0.005)$ and Leydig cells $(\mathrm{r}=-0.19, \mathrm{p}=0.02)$ when analyzed throughout the pregnancy. Although the gonad continues to grow and the testosterone concentration decreases after the seventh month of pregnancy, it was possible to identify a negative correlation between gonadal increase and the testosterone concentration. As previously mentioned, it is possible that part of the circulating testosterone was of an extra-gonadal origin, probably from the placenta, which would explain the lack of a positive correlation between the number of Leydig cells and the plasma testosterone concentration in fetuses.

Figure 2. Correlation between the number of Leydig cells and the fetal testicular weight $(\mathrm{r}=0.89 ; \mathrm{p}<0.0001)$ and fetal testicular volume $(\mathrm{r}=0.90 ; \mathrm{p}<0.0001)$, and the correlation between the number of Sertoli cells and testicular weight $(\mathrm{r}=0.84 ; \mathrm{p}<0.001)$ and testicular volume $(\mathrm{r}=0.92 ; \mathrm{p}<0.001)$ of 162 Nellore fetuses with gestational ages of 3 to 8 months
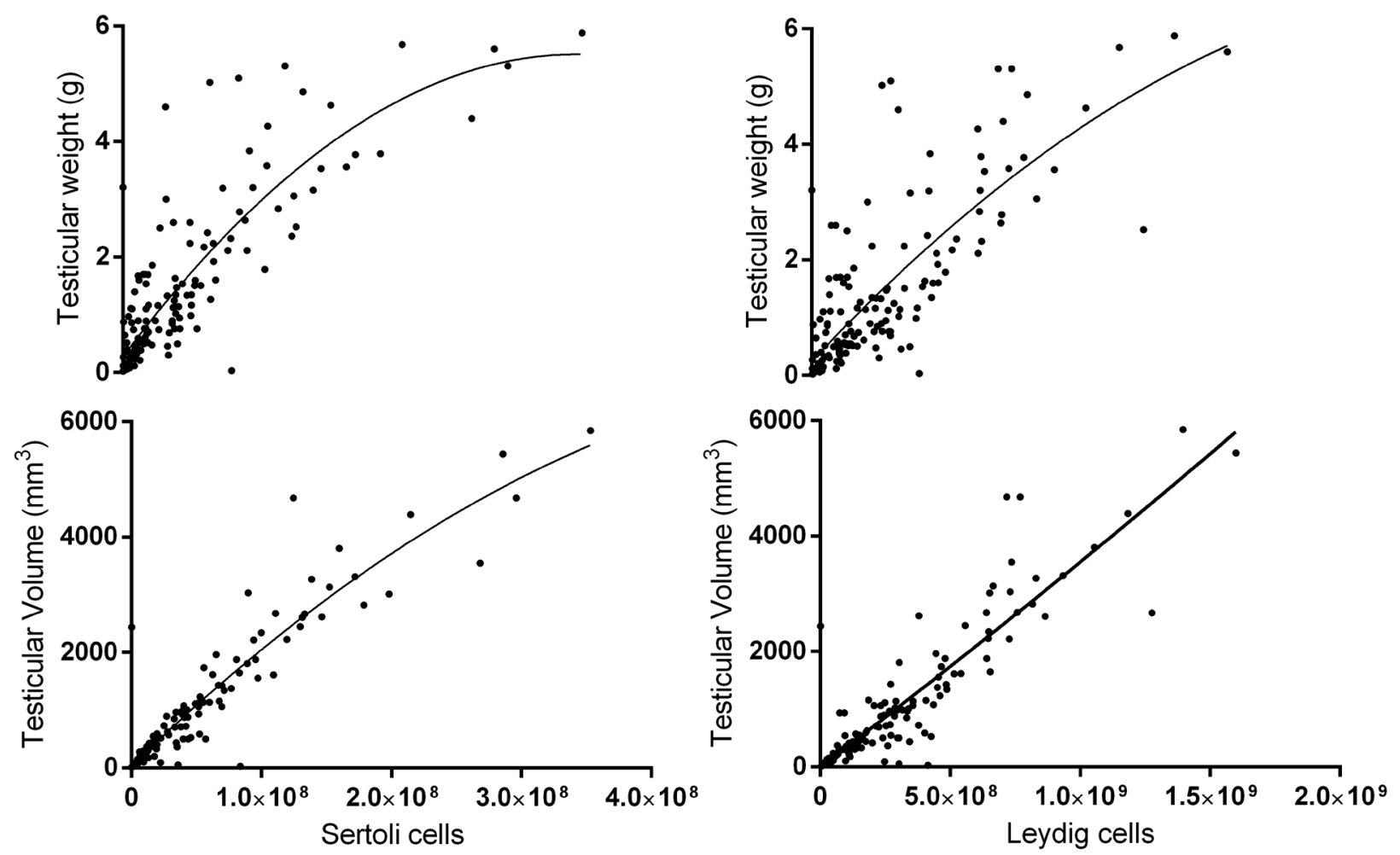

During the first 7 months of bovine pregnancy, male fetuses had a greater testosterone concentration than did female fetuses, but in the last two months, there was a decline in the male testosterone concentration, making this value equal to the testosterone concentration of female fetuses. In female fetuses, this variation in testosterone concentration was not observed (KIM et al., 1972),

reinforcing the idea of the extra gonadal origin of plasma testosterone in fetuses.

The high testosterone concentration during the beginning of pregnancy is important to differentiate both the internal and external genitalia and the central nervous system. After sexual differentiation and with the approach of birth, restraint of gonadal activity begins, follows the birth and continues until 
the appearance of secondary sexual characteristics close to puberty (NOGUEIRA, 2004).

The results described above were confirmed by a principal component analysis (PROC PCAPRINCOMP), which first establishes a correlation matrix between the variables and, through "eigenvalues" of the correlation matrix, indicates the most important variables for gonadal development. There was a homogeneous composition of the first principal component with equal weights for gonadal weight (0.35), volume (0.38), total number of cells (0.39), and the numbers of Sertoli cells (0.38), Leydig cells (0.38), and germ cells (0.38). The second principal component was the testosterone concentration (0.99). These two components (first and second) combined account for $93 \%$ of gonadal development. In summary, gonadal development depends on the quantity of cells to increase the weight and volume, and testosterone concentration also participates (but with a negative correlation).

Figure 3. Correlations between the testicular weight $(\mathrm{r}=-31 ; \mathrm{p}=0.001)$ and volume $(\mathrm{r}=-0.22 ; \mathrm{p}=0.006)$ and the numbers of Leydig cells $(r=-31 ; p=0.0001)$ and Sertoli cells $(r=-0.22 ; p=0.0006)$ and plasma testosterone concentration from 162 Nellore fetuses with gestational ages between 3 to 8 months.
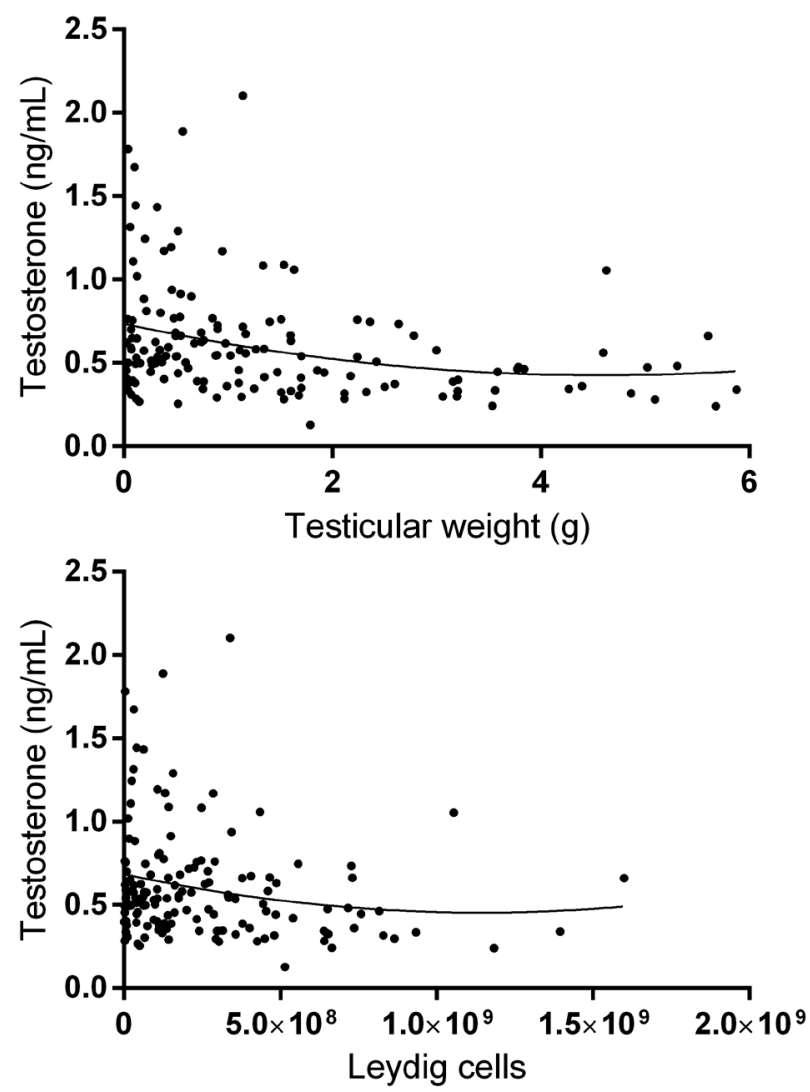

\section{Conclusion}

Fetal gonadal development depends upon the numbers of all cell types, but the testosterone concentration does not follow the increase in
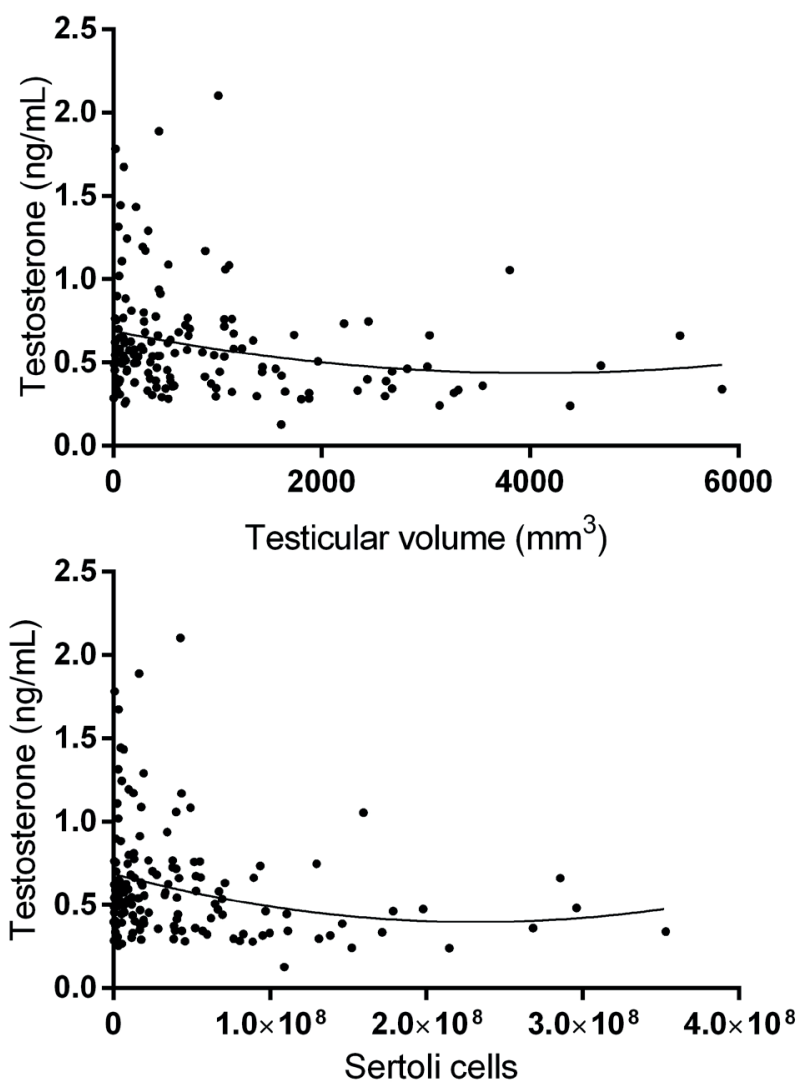

volume and weight of the testicle. The testosterone concentration decreased after the fifth month of pregnancy and declined thereafter, regardless of the increasing number of Leydig cells, suggesting extra gonadal production. 


\section{Acknowledgments}

To Fundação de Amparo à Pesquisa do Estado de São Paulo (FAPESP \# BMP 2011/15282-6; BEPE 2013/18200-6; APR 2011/50839-1) and to JBSAndradina slaughterhouse for allowing the fetal sample collection for this study.

\section{References}

AGUiAR, G. V.; ARAUJO, A. A.; MOURA, A. A. A. Desenvolvimento testicular, espermatogênese e concentrações hormonais em touros Angus. Revista Brasileira de Zootecnia, Viçosa, MG, v. 35, n. 4, p. 16291638, 2006.

ASSOCIAÇÃO DOS CRIADORES DE NELORE DO BRASIL-ACBN. Caracterização racial. 2013. Disponível em: $\quad<$ http://www.nelore.org.br/Raca/Caracterizacao $>$. Acesso em: 20 nov. 2013.

BERNDTSON, W. E.; IGBOELI, G.; PARKERM, W. G. The numbers of Sertoli cells in mature Holstein bulls and their relationship to quantitative aspects of spermatogenesis. Biology of Reproduction, Champaign, v. 37 , n. 1 , p. $60-67,1987$.

BRINKS, J. S.; MCINERNEY, M. J.; CHENOWETH, P. J. Relationship of age of puberty in heifers to reproductive traits in young bulls. Proceedings of the Western Section of American Society of Animal Science, Fort Collins, v. 29, p. 28-30, 1978.

CARDOSO, F. M. Desenvolvimento dos órgãos genitais masculinos de zebus (Bos indicus) da raça Nelore, do periodo fetal aos 36 meses de idade. 1977. Dissertação (Mestrado em Medicina Veterinária) - Universidade Federal de Minas Gerais, Belo Horizonte.

CARNEIRO JUNIOR, J.H.; RODRIGUES, G.; MOURA, A. Testicular development, peripheral concentrations of testosterone and histology of the seminiferous tubules in Nellore bulls. In: CONGRESSO DE INTEGRAÇÃO EM BIOLOGIA DA REPRODUÇÃO, 2001, Ribeirão Preto. Anais... Ribeirão Preto: USP, 2001. v. 2, p. 46. Resumo.

CONNOLlY, F.; RAE, M. T.; BITTNER, L.; HOGG, K.; McNEIL, Y.; DUNCAN, W. C. Excess androgens in utero alters fetal testis development. Endocrinology, Washington, v. 154, n. 5, p. 1921-1933, 2013.

CORTES, D.; MIILLER, J.; SKAKKEBEK, N. E. Proliferation of Sertoli cells during development of the human testis assessed by stereological methods. International Journal of Andrology, Malden, v. 10, n. 58, p. 596, 1987.
FORD, J. J.; D'OCCHIO, M. J. Differentiation of sexual behavior in cattle, sheep and swine. Journal of Animal Science, Champaign, v. 67, n. 7, p. 1816-1823, 1989.

FRANCAVILLA, S.; CORDESCHI, G.; PROPRZI, G., CONCORDIA, N., CAPPA, F., POZZI, V. Ultrastructure of fetal human gonad before sexual differentiation and during early testicular and ovarian development. Journal of Submicroscopic Cytology and Pathology, Bologna, v. 22, n. 3, p. 389-400, 1990.

GUERRA, A. G.; HENDRICK, S.; BARTH, A. D. Increase in average testis size of Canadian beef bulls. Canadian Veterinary Journal, Ottawa, v. 54, n. 5, p. 485490, 2013.

HOCHEREAU-DE REVIERS, M. T.; PERREAU, C.; PISSELET, C.; LOCATELLI, A.; BOSC, M. Ontogenesis of somatic and germ cells in sheep fetal testis. Journal of Reproduction and Fertility, Middlesex, v. 103, n. 1, p. 41-46, 1995.

JACOMINI, J. O.; ESPER, C. R.; DINIZ, E. G.; VIEIRA, R. C.; BELETTI, M. E. Morfogênese do testículo de embriões e fetos de vacas da raça Nelore (Bos taurus indicus). Brazilian Journal of Veterinary Research and Animal Science, São Paulo, v. 44, n. 1, p. 33-39, 2007.

JUNQUEIRA, L. C.; CARNEIRO, J. Histologia básica. Rio de Janeiro: Guanabara Koogan, 2004.

KAMINSKI, M. A.; CORBIN, C. J.; CONLEY, A. J. Development and differentiation of the interstitial and tubular compartments of fetal porcine testes. Biology of Reproduction, Champaign, v. 60, n. 1, p. 119-127, 1999.

KIM, C. K.; YEN, S. S. C.; BENIRSCHKE, K. Serum testosterone in fetal cattle. General and Comparative Endocrinology, New York, v. 18, n. 2, p. 404-407, 1972.

MACKAY, S. Gonadal development in mammals at the cellular and molecular levels. International Review of Cytology - A Survey of Cell Biology, Amsterdam, v. 200, p. 47-99, 2000.

MATSCHKE, G. H.; ERICKSON, B. H. Development and radioresponse of the prenatal bovine testis. Biology of Reproduction, Champaign, v. 1, n. 2, p. 207-214, 1969.

MENDIS-HANDAGAMA, S. M.; ARIYARATNE, H. B. Differentiation of the adult Leydig cell population in the postnatal testis. Biology of Reproduction, Champaign, v. 65, n. 3, p. 660-671, 2001.

MOSER, D. W.; BERRAND, J. K.; BENYSHEK, L. L.; McCANN, M. A.; KISER, E. Effects of selection for scrotal circumference in Limousin bulls on reproductive and growth traits of progeny. Journal of Animal Science, Champaign, v. 74, n. 9, p. 2052-2057, 1996. 
MOURA, A.; ERICKSON, B. H. Níveis hormonais durante a pré-puberdade como indicadores do desenvolvimento testicular em touros Angus. In: REUNIÃO ANUAL DA SOCIEDADE BRASILEIRA DE ZOOTECNIA, 34., 1997, Juiz de Fora. Anais... Juiz de Fora: Sociedade Brasileira de Zootecnia, 1997. p. 432434.

MULLER, J.; SKAKKEBAEK, N. E. Prenatal and postnatal development in testis. Bailliere's Clinical Endocrinology and Metabolism, London, v. 6, n.2, p. 251-272, 1992.

NOGUEIRA, G. P. Puberty in South American Bos indicus (Zebu) cattle. Animal Reproduction Science, Amsterdam, v. 82-83, p. 361-372, 2004.

PESSUTI, O.; MEZZADRI, F. P. Atualidade e perspectivas da pecuária paranaense. In: SIMPÓSIO INTERNACIONAL DE REPRODUÇÃO ANIMAL APLICADA, 1., Londrina. Anais... Londrina: UEM, 2004. p. 21-27.

REXROAD, C. E.; CASIDA, L. E.; TYLER, W. J. Crown rump length of fetuses, in purebred Holstein-Friesian cows. Journal of Dairy Science, Lancaster, v. 57, n. 3, p. 346-347, 1974.

REYNOLDS, L. P.; CATON, J. S. Role of the pre and post-natal environment in developmental programming of health and productivity. Molecular and Cellular Endocrinology, Amsterdam, v. 354, n. 1-2, p. 54-59, 2012.
REYNOLDS, L. P.; BOROWICZ, P. P.; CATON, J. S.; VONNAHME, K. A.; LUTHER, J. S.; HAMMER, C. J.; MADDOCK CARLIN, K. R.; GRAZUL-BILSKA, A. T.; REDMER, D. A. Developmental programming: the concept, large animal models, and the key role of uteroplacental vascular development. Journal of Animal Science, Champaign, v. 88, n. 13, p. E61-E72, 2010. Supplement.

SHARPE, R. M. C.; MCKINNELL, C.; KIVLIN, C.; FISHER, J. S. Proliferation and functional maturation of Sertoli cells, and relevance to disorders of testis function in adulthood. Reproduction, Cambridge, v. 125, n. 6, p. 769-784. 2003.

SVINGEN, T.; KOOPMAN, P. Building the mammalian testis: origins, differentiation, and assembly of the component cell populations. Genes and Development, Cold Spring Harbor, v. 27, n. 22, p. 2409-2426, 2013.

SWERDLOFF, C. W.; SINHA HIKIM, A. P. Hypothalamic-pituitary-gonadal axis in men. In: PFAFF, D. W.; ARNOLD, A. P.; FAHRBACH, S. E.; ETGEN, A. M.; RUBIN, R. T. (Org.). Hormones, brain and behavior. 2. ed. Cambridge: Academic Press, 2009. p. 2357-2393.

WROBEL, K-H.; SÜB, F. Identification and temporospatial distribution of bovine primordial germ cells prior to gonadal sexual differentiation. Anatomy Embryology (Berl), Berlin, v. 197, n. 6, p. 451-467, 1998. 